\title{
The use of epilithic diatoms grown on artificial substrata to indicate water quality changes in the lower reaches of the St Lucia Estuary, South Africa
}

\author{
Monique Nunes*, Janine B Adams and Guy C Bate \\ Botany Department, Institute for Coastal and Marine Research, Nelson Mandela Metropolitan University, PO Box 77000, \\ Port Elizabeth 6031, South Africa
}

\begin{abstract}
In shallow estuaries, artificial substrates provide a means of assessing the response of the diatom community to water chemistry. The shallow St Lucia Estuary was historically connected to the Mfolozi River at the mouth. This connection was severed during the early 1950s due to sediment input from the agriculturally impacted Mfolozi River. A connection has recently been re-established and the potential impact of dissolved inorganic nutrients from the Mfolozi River needs to be determined, as it may alter the ecological integrity of the St Lucia Estuary which forms part of a UNESCO World Heritage Site. This study found that the epilithic algal biomass and diatom species composition grown on glass slides were good indicators of nutrient enrichment in the estuary. Over a 28-day study period an above-average rainfall event resulted in an increase of nutrient-enriched freshwater flow into the estuary. No significant biomass differences were recorded in either the natural phytoplankton or microphytobenthos communities because of high variability. By contrast, the epilithic algal biomass accumulation on the glass slides was highest following the freshwater input. Statistical analyses indicated that the accumulation of the epilithic community on the glass slides was mostly affected by DIN and salinity. Diversity index scores for both the natural phytoplankton and microphytobenthos were variable, while the epilithic diatom index scores consistently declined from Day $7\left(H^{\prime}=1.2\right)$ to Day $28\left(H^{\prime}=0.7\right)$. These data indicate that epilithic algae grown on glass slides can be used as an effective monitoring tool to detect nutrient-induced changes as a supplementary method in this highly variable estuary.
\end{abstract}

Keywords: phytoplankton, microphytobenthos, epilithic, biomass, diversity, monitoring

\section{INTRODUCTION}

Situated at the boundary between land and sea, estuaries are facing increasing environmental pressure globally, largely due to the increasing human population and subsequent intensification of industrial and agricultural activities (O'Brien et al., 2016; Lemley et al., 2017). Anthropogenic stressors such as freshwater flow modifications, catchment land-use changes and exploitation of living resources (Bouvy et al., 2010; Van Niekerk et al., 2013) are known to impact estuarine health through changes in the biotic resource diversity and ecological functioning (O'Brien et al., 2016). Coupled with global-scale climate change, anthropogenically induced freshwater flow modifications are becoming increasingly prevalent (Mitchell et al., 2015). This is a matter of concern because freshwater flow is known to characterise the physical, chemical and biological condition within estuaries (Adams, 2014).

St Lucia, the largest estuarine lake in Africa, is known for its high natural variability (Gordon et al., 2016), consisting of a mosaic of different habitat types (Adams et al., 2013). Part of a UNESCO World Heritage Site and listed as a Ramsar Wetland of International Importance, the St Lucia estuarine system is a major destination for national and international eco-tourists and a regional economic centre (Whitfield and Taylor, 2009). Characterised by cyclical climate shifts between wet and dry periods, the freshwater supply to the estuarine system is derived from direct precipitation (50\%), river inflow (45\%) and groundwater recharge (5\%) (Taylor, 2006). Thus, between rainfall events, river inflow and groundwater recharge

\footnotetext{
To whom all correspondence should be addressed

e-mail: mnunes3712@gmail.com

Received 22 March 2018, accepted in revised form 5 January 2019.
}

are responsible for maintaining the shallow water depth ( $\leq 1 \mathrm{~m}$ depth). However, due to anthropogenic catchment land-use (e.g., commercial agriculture and forestry and the construction of water storage reservoirs), the freshwater inflow to the estuarine system has been considerably reduced which exacerbated the effects of periods of natural mouth closure and hypersalinity (Taylor, 2006).

The reduced freshwater inflow is largely attributed to the artificial separation of the joint inlet historically shared between the Mfolozi River and the St Lucia estuarine system in the early 1950s (Whitfield et al., 2013). The artificial separation of the two systems was in response to the high river sediment load as a direct result of agricultural activities (mainly sugarcane farming) in the Mfolozi River catchment. Subsequently, during the 2002-2012 drought the loss of 90\% of the estuarine water surface area, prolonged mouth closure and high salinity $(>200)$ were recorded because of the lack of freshwater (Carrasco et al., 2010; Perissinotto et al., 2013a; Tirok and Scharler, 2014). For this reason, re-establishing the connection between the agriculturally-impacted Mfolozi River and St Lucia estuarine system was reviewed and initiated in July 2012 to increase the freshwater inflow to the system (Bate et al., 2011; Whitfield, 2014). Although the St Lucia estuarine system is considered the most researched estuary in South Africa, most of these studies were conducted following the artificial separation of the joint inlet (Bate et al., 2011).

Despite the paucity of data on the St Lucia estuarine dynamics prior to the artificial separation of the joint inlet in the 1950s, it can be anticipated that the estuary will receive an uninterrupted supply of freshwater inflow from the agriculturally impacted Mfolozi River after the reconnection. Identified as one of four key sources of pollution in South Africa, agricultural runoff is known to introduce nutrients 
originating from abundant fertilization and increase sediment loads, because of poor catchment management, into estuaries (Van Niekerk et al., 2013). Therefore, the nutrient input from the Mfolozi River needs to be monitored to detect any potential change in the ecological integrity of the estuary. The Mfolozi River catchment's potential for eutrophication was validated by the long-term water quality data (1995-2016) that indicated an increased occurrence of nutrient-enriched conditions (of between 20 and 50\%) (Nunes et al., 2018).

A recent study by Nunes et al. (2017) showed the nutrientenriched nature of the Mfolozi River inflow; however, none of the expected eutrophic responses associated with anthropogenic nutrient loading (e.g., accelerated phytoplankton growth and the proliferations of harmful/toxic algal blooms) were recorded (Lemley et al., 2015; Lemley et al., 2017). This response has also been observed in other estuaries such as the Marano and Grado Lagoon in the Mediterranean (Acquavita et al., 2015) and the Patos Lagoon in southern Brazil (Odebrecht et al., 2015) where, despite nutrient enrichment, altered water residence times inhibited net algal growth rates and biomass accumulation.

Phytoplankton and diatom communities are often used as indicators of ecosystem health because they are the major primary producers in aquatic ecosystems and are also generally the first to respond to anthropogenic disturbances (Rodriguez and Pizarro, 2015; Lemley et al., 2016). Therefore, due to the increased freshwater inflow that led to phytoplankton biomass dilution and resuspension of benthic diatoms, the use of artificial substrates as a monitoring tool has been recommended (Nunes et al., 2017). The benefits of using artificial substrates include standardized comparisons among sampling sites (Dela-Cruz et al., 2006), high accuracy in the measurements (Sanchez et al., 2017), uniformity of the surface, decreased habitat disruption (Dalu et al., 2014) and the development of a diatom community exclusively influenced by water column chemistry (Desrosiers et al., 2013).

Since ecosystem recovery can be slow once an ecological threshold has been exceeded, it is vital to detect early signs of large-scale ecosystem shifts, and monitoring of microalgal communities is a means to do so for estuarine systems (Paerl et al., 2010; Peirson et al., 2015). Because freshwater inflow is currently limiting the microalgal growth in the St Lucia Estuary, this study aimed to test the efficacy of using the microalgal community associated with artificial substrates to assess the changes in the water quality as a supplementary method to the more traditional approaches (i.e. phytoplankton and microphytobenthos).

\section{MATERIALS AND METHODS}

\section{Study site}

The St Lucia estuarine system is situated in the northern part of KwaZulu-Natal in the subtropical biogeographical region of South Africa, forming part of the iSimangaliso Wetland Park, a conservation area of international importance. It has four physically distinct regions consisting of three interconnected shallow lakes, i.e., False Bay, North Lake, South Lake and the Narrows. This study focused on the St Lucia Estuary which includes the area from the mouth to the lower parts of the Narrows (Fig. 1) (Perissinotto et al., 2013b). As theft or vandalism has been identified as a key consideration for site

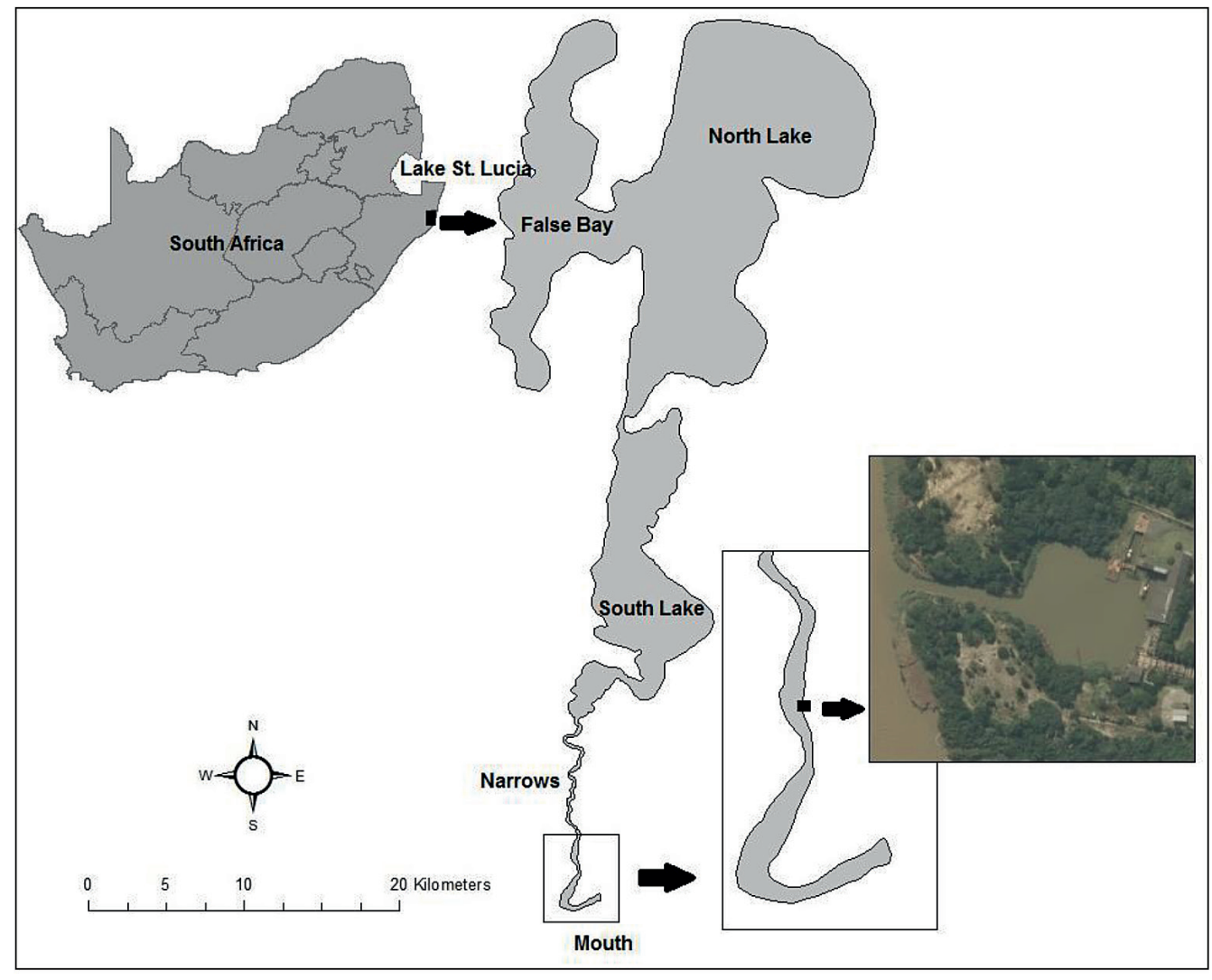

Figure 1

The location of the study site at Ezemvelo KwaZulu-Natal Wildlife harbour in the St Lucia Estuary 
selection when deploying artificial structures for water quality monitoring (Chapman et al., 1996), the Ezemvelo KwaZuluNatal Wildlife harbour was selected. Access to the harbour is security controlled and its proximity to the mouth ensures that any freshwater inflow from the Mfolozi River will be reflected in the ambient environmental conditions. To ensure minimal disturbance by boating or human activities, the artificial structure was deployed from the dry dock. Therefore, one site (GPS coordinates: $-28.362031,32.411242$ ) (Fig. 1) in the lower reaches of the estuary was sampled weekly in winter from 19 July 2016 to 16 August 2016. All data collection was conducted within a $1 \mathrm{~m}$ radius of the deployed artificial substrata in the harbour.

\section{Hydrodynamic and climatological data}

Daily river flow data were obtained from the South African Department of Water and Sanitation's W2H032 gauge for the Mfolozi River located on the lower floodplain. Rainfall data were obtained from the South African Sugarcane Research Institute (SASRI) automated weather station situated near the estuary.

\section{Physico-chemical and inorganic nutrient variables}

Physico-chemical parameters were measured weekly at the surface and bottom of the water column using a Hanna HI98194 multiprobe. The parameters recorded included dissolved oxygen $\left(\mathrm{mg} \cdot \mathrm{L}^{-1}\right)$, $\mathrm{pH}$, salinity and water column temperature $\left({ }^{\circ} \mathrm{C}\right)$. Water depth $(\mathrm{m})$ measurements were recorded using a measuring stick and Secchi depth (m) measurements (water clarity) using a Secchi disc. Water samples (3 replicates per week) for total oxidised nitrogen $\left(\mathrm{NO}_{3}^{-}+\mathrm{NO}_{2}^{-}\right)$, ammonium $\left(\mathrm{NH}_{4}^{+}\right)$and soluble reactive phosphorus $\left(\mathrm{PO}_{4}^{3-}\right)$ determination were collected at the midposition of the water column. Water samples were collected using a $500 \mathrm{~mL}$ weighted pop-bottle. Due to the fine silt particles present in the estuary water, a 2-step filtration process was adopted. Immediately after collection the water samples were vacuum-filtered through glass-fibre filters (Whatman GF/F) and subsequently re-filtered through hydrophilic polyvinylidene difluoride (PVDF) $0.47 \mu \mathrm{m}$ pore-size syringe filters. The filtrates were stored in $250 \mathrm{~mL}$ acid-washed polyethylene screw-cap bottles and frozen at $-20^{\circ} \mathrm{C}$ until analysis. The reduced copper cadmium method as described by Bate and Heelas (1975) was used to analyse the water samples for total oxidised nitrogen. The analyses for ammonium and soluble reactive phosphorus were done using standard spectrophotometric methods (Parsons et al., 1984). Inorganic nutrients were categorized as dissolved inorganic nitrogen $\left(\mathrm{DIN}=\mathrm{NO}_{3}{ }^{-} \mathrm{N}+\mathrm{NO}_{2}{ }^{-} \mathrm{N}+\mathrm{NH}_{4}{ }^{+}-\mathrm{N}\right)$ and dissolved inorganic phosphorus (DIP $=\mathrm{PO}_{4}^{3-}-\mathrm{P}$ ).

\section{Artificial substrata}

The artificial substrata used in this study were microscope glass slides $(25 \times 75 \mathrm{~mm})$ housed in an open-sided aluminium frame (Plate 1). The artificial structure was suspended just below the water surface on a rope attached to the dry dock in the Ezemvelo KwaZulu-Natal Wildlife harbour and held in place by series of floats, ropes and weights. Slides were collected every week, at random positions, to assess the recruitment and colonisation by epilithic diatoms. The optimal colonisation time for maximum epilithic biomass development in freshwater systems is estimated at 2 to 4 weeks (Dalu et al., 2014; Casartelli et al., 2016), while in marine systems it is estimated at 5 weeks (Desrosiers et al., 2014). However, in a nutrient-enriched permanently open estuarine system the artificial substrata were found colonized by macroalgae before reaching the 30-day deployment period (Minne, 2003). Considering that the St Lucia Estuary has been subjected to nutrient enrichment from the Mfolozi River inflow (Nunes et al., 2017), the artificial substrata used in this study were deployed for a total period of 4 weeks ( 28 days) to avoid the development of macroalgae on the glass slides.

\section{Primary producers}

The primary producers assessed included: phytoplankton inhabiting the water column; microphytobenthos inhabiting the subtidal benthic environment and epilithon grown on the artificial substrata, i.e., glass microscope slides (Eulin and Le Cohu, 1998; Lemley et al., 2016). Due to their good performance as ecological indicators, diatoms were selected as representative of the different primary producer communities (Elias et al., 2017).

\section{Microalgal biomass}

Three replicates each of water samples for phytoplankton biomass, subtidal sediment samples for microphytobenthos (MPB) biomass and glass slides for epilithic biomass were collected weekly. Chlorophyll $a$ (chl-a) was used as a proxy for phytoplankton, MPB and epilithic biomass. To determine the phytoplankton chl- $a$, water samples were collected at the mid-position of the water column using a $500 \mathrm{~mL}$ weighted pop-bottle. After collection, they were gravity filtered through Munktell MGC glass-fibre filters and then frozen until analysis. The chlorophyll $a$ was extracted overnight in the laboratory by placing the filters into glass vials containing $10 \mathrm{~mL}$ of $95 \%$ ethanol (Merck 4111).

For the MPB chl- $a$ determination, subtidal sediment samples were collected using a $20 \mathrm{~mm}$ internal diameter corer attached to an extension pole. The top $1 \mathrm{~cm}$ of the sediment was scraped from each core and was stored separately in $60 \mathrm{~mL}$ polyethylene bottles. The sediment samples were frozen and

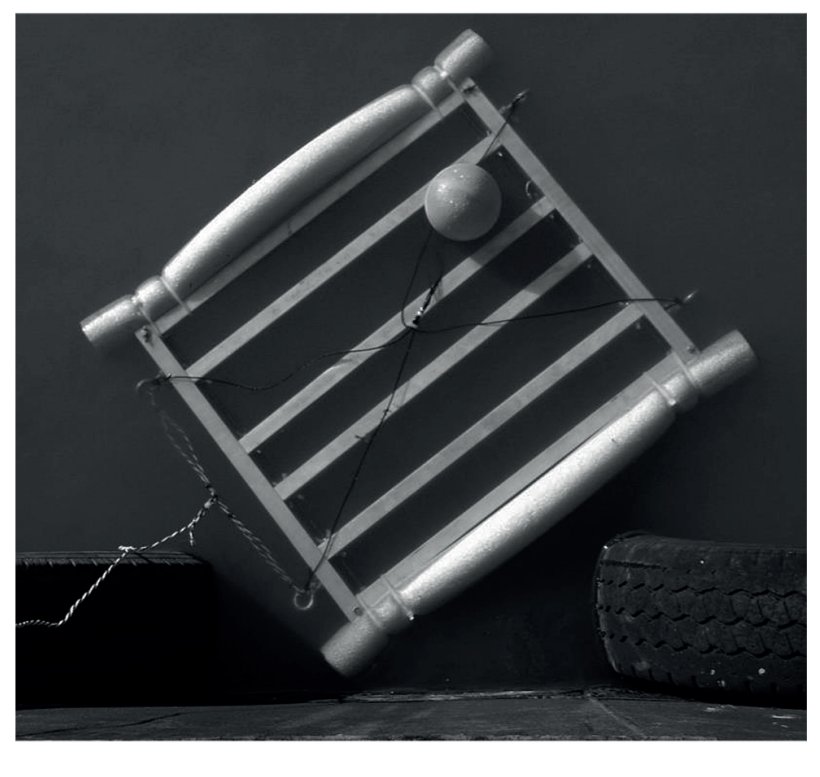

Plate 1

The artificial structure used during the 4-week study period 
kept in the dark before being freeze-dried in the Secfroid Lausanne Suisse freeze-drier overnight. The chlorophyll $a$ was extracted by adding $15 \mathrm{~mL}$ of $95 \%$ ethanol (Merck 4111).

To determine the epilithic chl- $a$, the glass slides were individually scraped with a razor blade and rinsed onto separate Munktell MGC glass-fibre filters using $50 \mathrm{~mL}$ of filtered estuarine water. The estuarine water used was filter-sterilised using a Merck $0.2 \mu \mathrm{m}$ nylon filter (Andersen, 2005). The samples were frozen until analysis. The chlorophyll $a$ was extracted in the dark for $12 \mathrm{~h}$ into $10 \mathrm{~mL}$ of $95 \%$ ethanol (Merck 4111) at 1 to $2^{\circ} \mathrm{C}$.

The phytoplankton, MPB and epilithic chl- $a$ extracts were filtered using Munktell MGC glass-fibre filters and the light absorbance of the supernatant read using a GBC UV/VIS spectrophotometer (GBC UV/VIS 916, GBC Scientific equipment (Pty) Ltd 1995) at $665 \mathrm{~nm}$ before and after acidification with 1-2 drops of $1 \mathrm{~N} \mathrm{HCl}$. The chl- $a$ concentrations were determined using the spectrophotometric method described by Hilmer (1990) as derived from Nusch (1980). The MPB and epilithic chl- $a$ was expressed as $\mathrm{mg} \cdot \mathrm{m}^{-2}$.

\section{Diatom community composition}

For diatom identification, 3 replicate samples each for the planktonic diatom community $(250 \mathrm{~mL})$, subtidal sediment samples for the benthic diatom community and glass slides for the epilithic diatom community were collected weekly. Both sides of the glass slides were brushed with a toothbrush (to prevent damaging the diatom valves) and the recovered material was pooled in a single storage $250 \mathrm{~mL}$ bottle with filter-sterilized estuarine water (Andersen, 2005). The material from the three glass slides was pooled each week to form one composite sample. The water samples (planktonic and epilithic) were preserved with glutaraldehyde. The sediment samples were collected and processed according to the cover slip method described by Round (1981) and Bate et al. (2004). The sample preparation process for diatom identification was performed according to the method described by Taylor et al. (2007) and Bate et al. (2013).

The diatom frustules were examined, identified and counted using a Zeiss Axioplan light microscope with differential interference contrast (DIC) optics. Using a television camera (The Imaging Source DFK 41F02), images of the dominant species were visualised using the Analysis image analysis programme (Software Imaging System $\mathrm{GmbH}, 2016)$. At least one micrograph of every taxon was captured. A minimum of 400 diatom valves were counted and determined to species level (or genus level when species was not possible) using the taxonomic guides by Bate et al. (2004), Hartley (1996), Lange-Bertalot (2000), Round et al. (1990) and Taylor et al. (2007). The dominants were those species that were clearly present in the greatest number and the sub-dominants were those that had a frequency $>10 \%$ but were not dominant in the total count. Once the diatom communities had been counted and identified, the Shannon diversity index $\left(H^{\prime}\right)$, evenness of species distribution $\left(J^{\prime}\right)$, and species richness $(S)$ were determined for the planktonic, benthic and epilithic diatom community (Shannon and Weaver, 1949).

\section{Data analysis}

Statistical analyses were conducted using Dell Statistica Version 13 (Dell Inc., 2016). All analyses were done at a significance level of $\infty<0.05$. The Shapiro-Wilk' W test was used to test for normality. Data were log-transformed to satisfy normality assumptions when data were skewed. Differences in initial water column chemistry variables (salinity, water column temperature, dissolved oxygen, $\mathrm{pH}$, TSS, DIN and DIP) and chl- $a$ concentration between weeks were determined using a one-way analysis of variance (ANOVA). A post-hoc comparison of significantly different means was done using Tukey's Honest Significant Difference test. Pearson's product moment correlation coefficient formula was used to test for relationships between the water column chemistry variables and the phytoplankton, microphytobenthos and epilithic biomass.

\section{RESULTS}

\section{Hydrodynamic and climatological data}

Prior to the sampling period from 19 July 2016 to 16 August 2016, the area received only a few isolated rainfall events (Fig. 2). However, the above-average rainfall received between

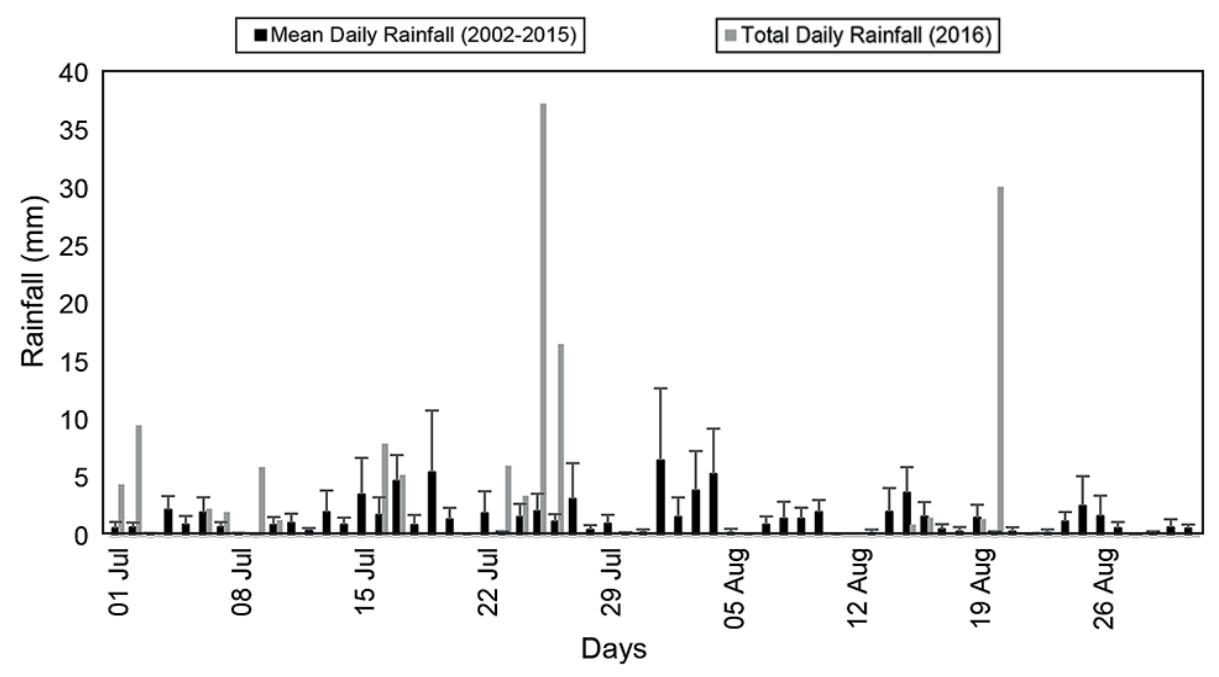

Figure 2

Mean daily historical rainfall (mean + SE) and total daily rainfall received in the St Lucia town from 1 July until 31 August 
23 July 2016 and 26 July 2016 (4 days) produced a strong inflow of freshwater from the Mfolozi River into the St Lucia Estuary (Fig. 3; Plate 2). In response to the freshwater input, the water level in the estuary increased and salinity decreased from Day 0 to Day 14 (Fig. 4). However, in the absence of further rainfall (Fig. 2) the water level steadily decreased, and salinity increased from Day 14 to Day 28 (Fig. 4).

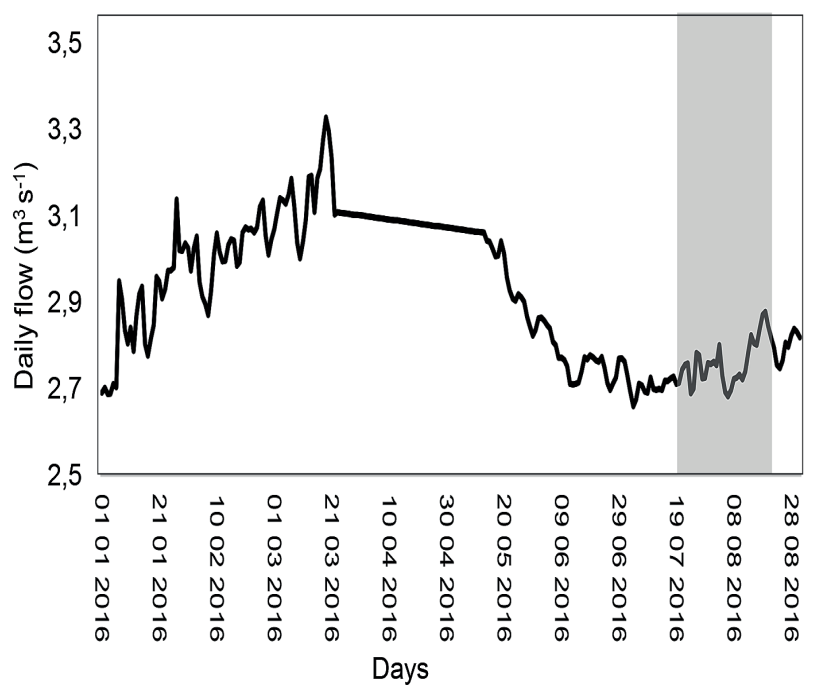

Figure 3

Daily average flow of the Mfolozi River (W2H032) from 01/01/2016 to 30/08/2016. The shaded area indicates the study period

\section{Physico-chemical variables}

Significant changes in water quality parameters (Table 1) were observed at the onset of freshwater inflow from the Mfolozi River. Temperature $(p<0.001, F=535.2, \mathrm{df}=4)$, salinity $(p<0.01, F=12.9, \mathrm{df}=4)$, DO $(p<0.01, F=21.8$, $\mathrm{df}=4)$ and TSS $(p<0.001, F=14.8, \mathrm{df}=4)$ differed between weeks, while $\mathrm{pH}$ (Table 1) and DIP (Fig. 5a) remained consistent $(p>0.05)$.

The most pronounced difference was observed for DIN (Fig. 5b). The DIN concentrations were significantly different during Day 0 and Day $7(p<0.001, F=72.8, \mathrm{df}=4)$. However,

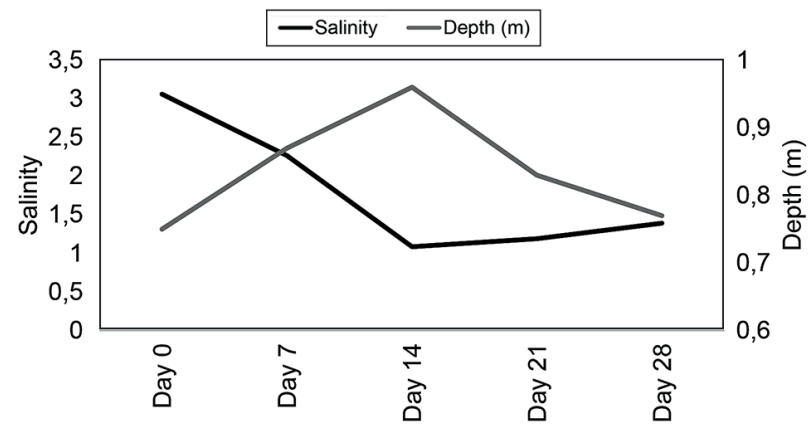

Figure 4

Salinity and water depth $(m)$ recorded weekly at the study site in the St Lucia Estuary for the duration of the study period 19 July to 16 August 2016

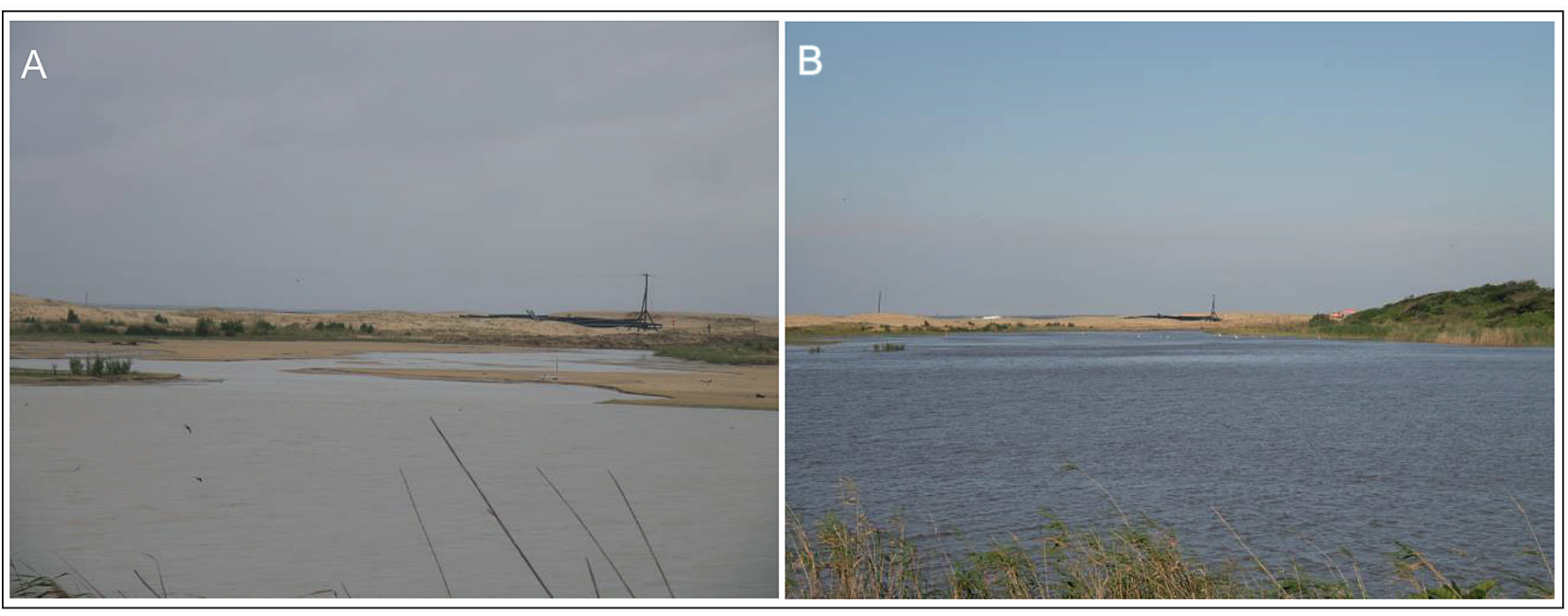

Plate 2

The water level in the Beach channel connecting the Mfolozi River and the St Lucia Estuary before (A - 24 July 2016) and after (B-27 July 2016) an above-average rainfall event

TABLE 1

Mean $( \pm \mathrm{SE})$ of the physico-chemical parameters and nutrient concentrations measured over the 5 -week study period

\begin{tabular}{|c|c|c|c|c|c|}
\hline Parameter & Day 0 & Day 7 & Day $14^{*}$ & Day 21 & Day 28 \\
\hline Temperature $\left({ }^{\circ} \mathrm{C}\right)$ & $17.6 \pm 0.03$ & $18.2 \pm 0.06$ & $17.7 \pm 0.02$ & $17.4 \pm 0.02$ & $19.3 \pm 0.01$ \\
\hline Salinity & $3.1 \pm 0$ & $2.3 \pm 0.5$ & $1.1 \pm 0.01$ & $1.2 \pm 0.01$ & $1.4 \pm 0$ \\
\hline $\mathrm{pH}$ & $7.7 \pm 0$ & $7.6 \pm 0.05$ & $7.3 \pm 0.1$ & $6.9 \pm 0.3$ & $7.2 \pm 0.1$ \\
\hline $\mathrm{DO}\left(\mathrm{mg} \cdot \mathrm{L}^{-1}\right)$ & $5.1 \pm 0.2$ & $7.0 \pm 0.5$ & $3.9 \pm 0.1$ & $6.1 \pm 0.2$ & $4.8 \pm 0.03$ \\
\hline TSS (mg. $\left.\mathrm{L}^{-1}\right)$ & $0.023 \pm 0.001$ & $0.019 \pm 0.001$ & $0.017 \pm 0.0003$ & $0.024 \pm 0.001$ & $0.019 \pm 0.0001$ \\
\hline
\end{tabular}

*indicates the peak freshwater inflow from the Mfolozi River 

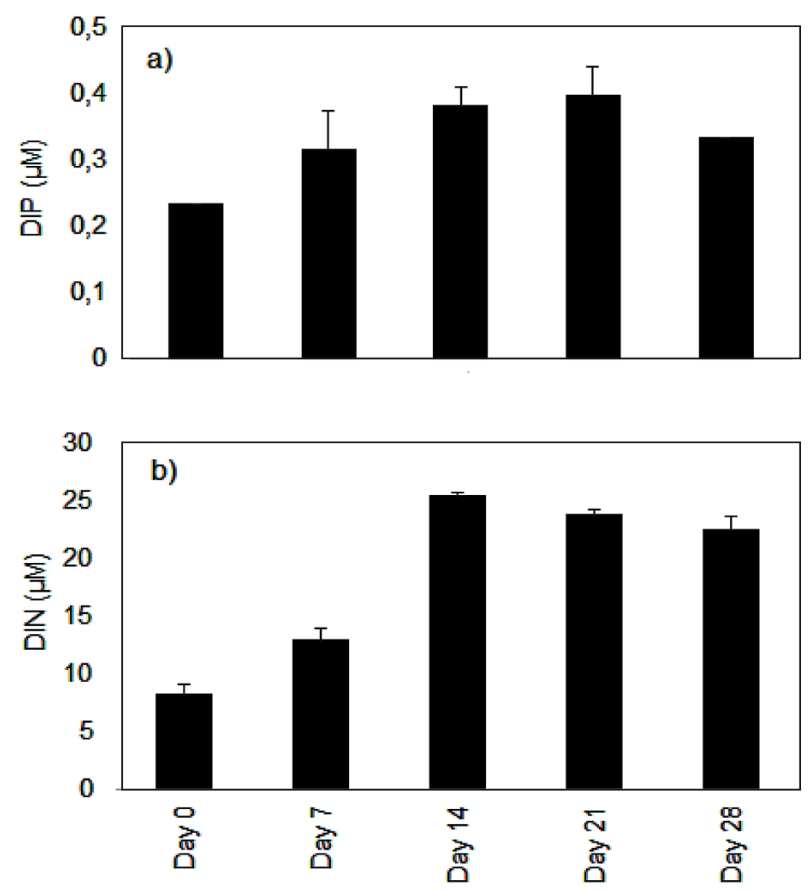

Figure 5

(a) DIP and (b) DIN recorded weekly at the study site in the St Lucia Estuary for the duration of the study period, 19 July to 16 August 2016

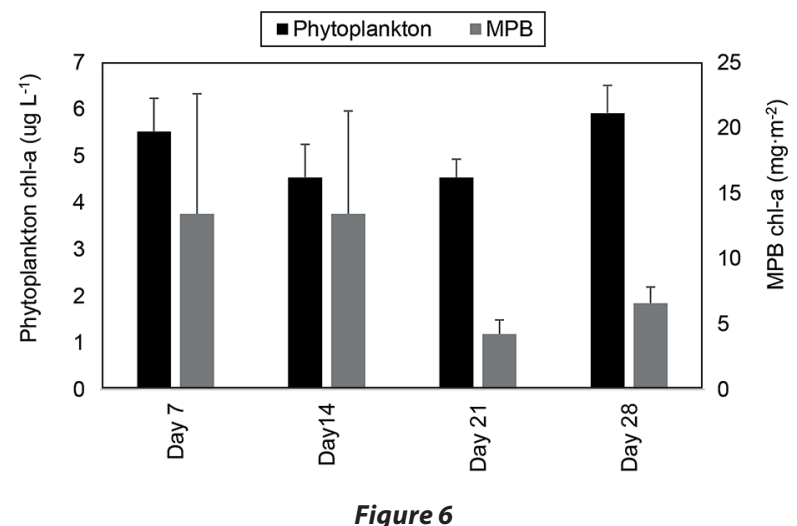

Weekly changes (mean \pm SE) in the phytoplankton and MPB chlorophyl a concentrations recorded at the study site in the St Lucia Estuary for the duration of the study period, 19 July to 16 August 2016

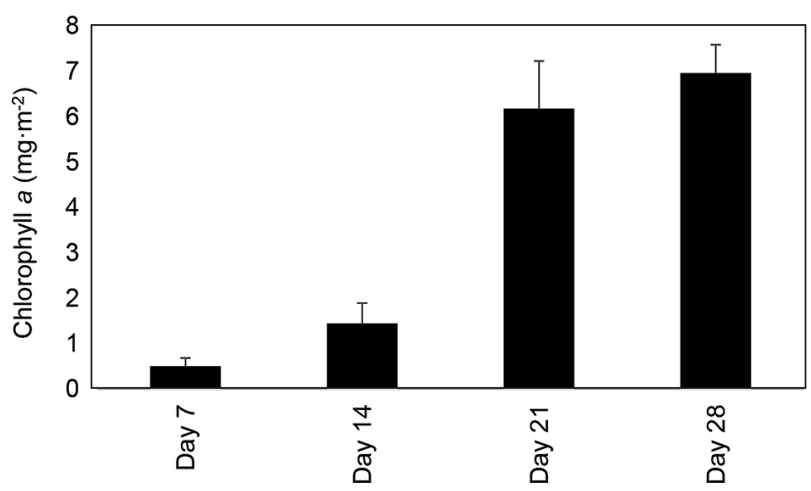

Figure 7

Weekly changes (mean $\pm S E$ ) in the epilithic chl-a concentrations recorded on the glass slides for the duration of the study period, 19 July to 16 August 2016 during the period under consideration, DIN concentrations, particularly nitrate, increased exponentially during Day 14 in response to the freshwater input from the Mfolozi River $(p<0.01)$. No significant difference was observed between Days 14,21 and $28(p>0.05)$.

\section{Microalgal biomass}

The average phytoplankton chl- $a$ concentrations were $5.5 \pm 0.7 \mu \mathrm{g} \cdot \mathrm{L}^{-1}$ on Day $7,4.5 \pm 0.7 \mu \mathrm{g} \cdot \mathrm{L}^{-1}$ on Day $14,4.5 \pm 0.4 \mu \mathrm{g} \cdot \mathrm{L}^{-1}$ on Day 21 and $5.9 \pm 0.6 \mu \mathrm{g} \cdot \mathrm{L}^{-1}$ by Day 28 (Fig. 6). Average benthic chl- $a$ concentrations were $13.4 \pm 9.2 \mathrm{mg} \cdot \mathrm{m}^{-2}$ on Day 7 , $13.4 \pm 7.9 \mathrm{mg} \cdot \mathrm{m}^{-2}$ on Day 14, $4.2 \pm 1.1 \mathrm{mg} \cdot \mathrm{m}^{-2}$ on Day 21 and $6.5 \pm 1.3 \mathrm{mg} \cdot \mathrm{m}^{-2}$ by Day 28 (Fig. 6). No significant differences were observed between the weekly phytoplankton and benthic chl- $a$ concentrations $(p>0.05)$. Furthermore, the correlation analyses showed no significant relationship between the phytoplankton and benthic chl- $a$ concentrations and the physico-chemical parameters $(p>0.05)$.

The average epilithic chl- $a$ concentrations were $0.5 \pm 0.2 \mathrm{mg} \cdot \mathrm{m}^{-2}$ on Day 7, $1.5 \pm 0.5 \mathrm{mg} \cdot \mathrm{m}^{-2}$ on Day $14,6.2 \pm 1.1 \mathrm{mg} \cdot \mathrm{m}^{-2}$ on Day 21 and $7.0 \pm 0.6 \mathrm{mg} \cdot \mathrm{m}^{-2}$ by Day 28 (Fig. 7). Unlike the phytoplankton and benthic chl- $a$ concentrations, significant differences were observed in the epilithic chl- $a$ concentrations during the different weeks $(p<0.001, F=24.9, \mathrm{df}=3)$. Significant differences were observed when comparing Day 7 and Day 14 to Day 21 and Day $28(p<0.05)$. There was also a significant relationship between salinity and the epilithic chl- $a$ concentrations $(r=-0.6, p<0.05)$ and between DIN and the epilithic chl- $a$ concentrations $(r=0.7, p<0.05)$.

\section{Diatom community composition}

A total of 18, 23 and 20 different taxa were recorded for planktonic, benthic and epilithic diatom communities, respectively (Fig. $8_{\mathrm{B}}$ ). The indices scores for distribution of both the planktonic and benthic diatom communities followed the same trend, peaking on Day 21 (Fig. $8_{\mathrm{ABC}}$ ). By contrast, the index scores for the epilithic diatom community gradually decreased (Fig. $8_{\mathrm{ABC}}$ ).

The planktonic diatom community was dominated by Cyclotella atomus and Frustulia sp. by Day 7, Nitzschia palea and C. atomus by Day 14, Diploneis smithii, Nitzschia agnewii, C. atomus and Synedra fasciculata on Day 21 and by D. smithii and $C$. atomus on Day 28. The benthic diatom community was dominated by D. smithii, Hyalodiscus radiatus, and C. atomus on Day 7, Cocconeis placentula var. euglypta and D. smithii on Day 14, Amphora coffeiformis, D. smithii, C. atomus and S. fasciculate on Day 21 and Diatoma vulgaris and C. atomus on Day 28. The dominant diatom species collected from the epilithic diatom community remained more consistent. C. placentula var euglypta and Synedra fasciculata were dominant on Day 7 while C. placentula var. euglypta (>70\%) remained dominant throughout the remainder of the study period (Fig. 9).

\section{DISCUSSION}

Understanding the drivers responsible for the gain or loss of microalgal diversity and biomass is important to accurately relate a certain response to a component of anthropogenically derived stress. In principle, phytoplankton growth is regulated by light, temperature and nutrient availability; while grazing, dilution/flushing, cell death and sedimentation constitute 

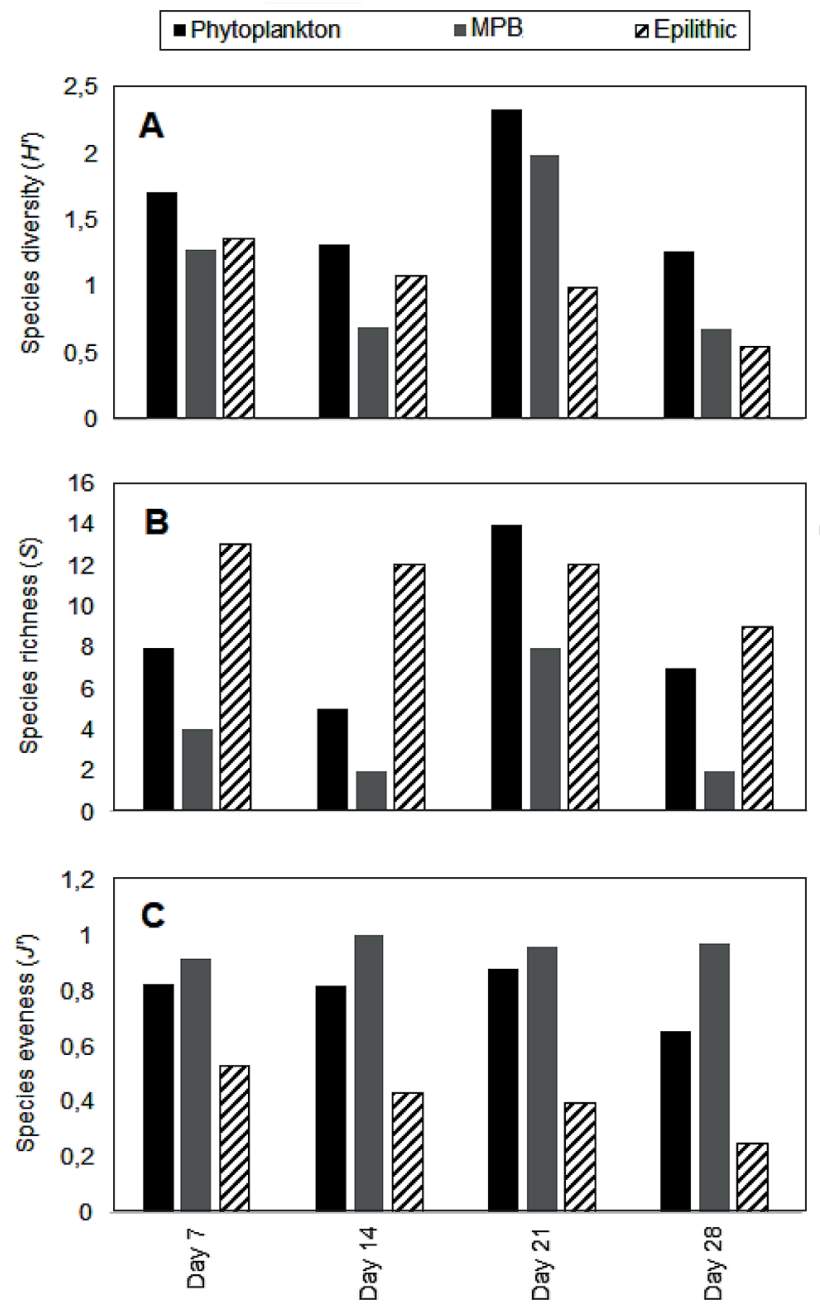

Figure 8

Comparison of the $(A)$ diversity index scores, $(B)$ species richness and $(C)$ evenness of species distribution scores per diatom community per week

loss (Dix et al., 2013). Similar regulatory drivers apply to microphytobenthos (MPB) populations, with sediment type, organic content and particle size providing additional factors (Aktan et al., 2014). However, although various methods centred on community structural variables (species richness, biomass, diversity and evenness indices) are accepted for detecting anthropogenic-induced change, in naturally stressed ecosystems such as estuaries, distinguishing between natural and anthropogenic factors can often be difficult (Elliot and Quintino, 2007; Tweedley et al., 2015). For this reason, a multimetric approach incorporating both water chemistry variables and structural variables, is generally considered more accurate (Lemley et al., 2015) for extrapolating the anthropogenic signal from the background noise (Elliot and Quintino, 2007). This study investigated the use of the epilithic algal biomass and diatom species composition on an artificial substrate, i.e., glass microscope slides as indicators of change in the St Lucia Estuary, thus minimising some of the factors that account for variation.

Based on the estuarine eutrophic condition index (Lemley et al., 2015), the St Lucia Estuary was in a mesotrophic state during the study period. This was attributed to the water chemistry variables (DIN, DIP and dissolved oxygen) and microalgal biomass variables (phytoplankton and MPB) falling within the 'Good' to 'Fair' range, while the diversity index was

\begin{tabular}{|c|c|c|c|}
\hline - SYNEFASC & 冈 NITZPALE & $\square$ NITZAGNE & •FRUSTULI \\
\hline DIPLSMIT & ๑CYCLGLOM & घ CYCLATOM & GHYALRADI \\
\hline XOCCPLAC & $\square$ AMPHCOFF & 口DIATVULG & \\
\hline
\end{tabular}
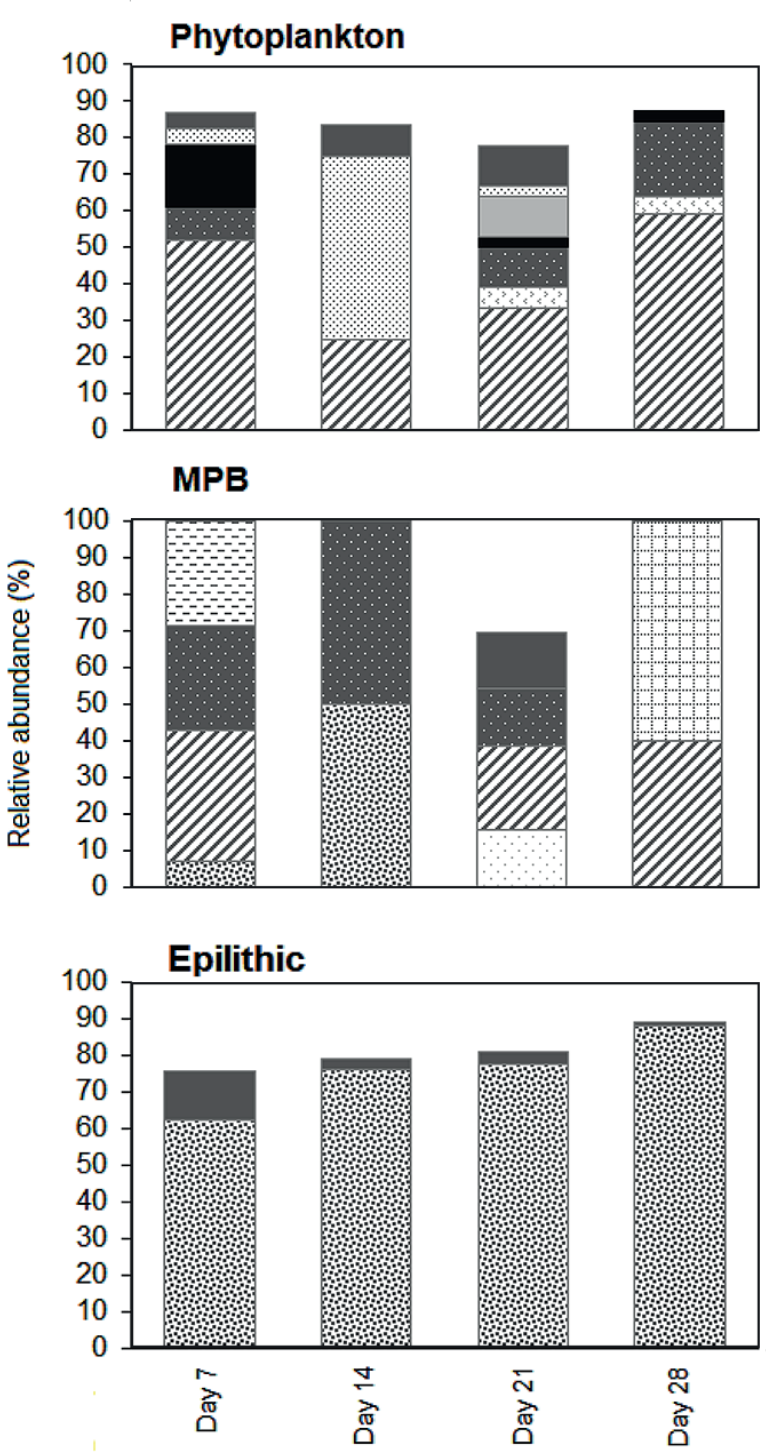

Figure 9

Comparison of the relative abundance of the dominant diatoms species (> 10\%) recorded weekly for (A) the planktonic diatom community, (B) the benthic diatom community and $(C)$ the epilithic diatom community. List of dominant diatom species in Table A1, Appendix.

classified as 'Poor' (Lemley et al., 2015). Although the St Lucia Estuary would naturally be in an oligotrophic state, higher nutrient values in the estuary are generally associated with freshwater inflow from the rivers (Perissinotto et al., 2013a). This was especially evident during this study since the DIN concentrations at the study site increased from $8.3 \mu \mathrm{M}$ (Day 0) to $25.4 \mu \mathrm{M}$ (Day 14) following the freshwater inflow from the Mfolozi River. This is further evidenced by the water quality data, routinely collected in the Mfolozi River, that reported a DIN load of $40 \mathrm{~kg} \mathrm{~N} \cdot \mathrm{d}^{-1}$ on 12 July 2016 (prior the rainfall event) and $141 \mathrm{~kg} \mathrm{~N} \cdot \mathrm{d}^{-1}$ on 9 August 2016, i.e., Day 21 of this study (DWS, 2017). This represents an approximate 3.5-fold increase in the DIN supply concomitant with the pulse event recorded during this study. The DIN supply is attributed to the 
sugarcane farming that accounts for the largest modification of the Mfolozi catchment (Grenfell and Ellery, 2009).

In freshwater ecosystems, an increasing availability of nutrients such as nitrate and phosphate, introduced via fertilizers or sewage, is commonly associated with eutrophication and known for influencing the productivity and community structure of primary producers (Delgado and Pardo, 2014). For example, in the agriculturally influenced Gamtoos Estuary, South Africa, a sustained increase in river flow (high flow period) has been shown to shift the system from an oligotrophic to eutrophic state, facilitating biomass accumulation for both the phytoplankton and MPB (Lemley et al. 2017). In contrast, results from this study showed that the phytoplankton and MPB biomass was variable because no distinct pattern was observed when compared to the growth of the epilithon on the glass slides, which showed an increase in biomass. This was despite a 2-week lag period, where phytoplankton and MPB accrual could have been expected in response to the increased nutrient availability, as highlighted by Lemley et al. (2018). Results from a 28-day microcosm experiment in a relatively pristine estuary along the south coast of South Africa indicated that the treatment with the highest nitrate additions exhibited the highest phytoplankton and MPB biomass.

The interactions between benthic and pelagic processes are more direct in turbid, shallow waters, such as in the St Lucia Estuary. Rapid interchange between communities (i.e. resuspension) and low water residence time has previously been shown to hinder microalgal growth in the estuary in a wet phase (Nunes et al., 2017). The lower MPB biomass observed on Day 21 in this study can therefore be assigned to reduced community stability during more turbulent hydrological conditions, i.e., elevated freshwater inflow (Snow, 2016), coupled with wind-driven circulation (Bate et al., 2013). The diversity index, species richness and evenness scores for both the planktonic and benthic diatom communities had increased by Day 21. Of the dominant diatoms identified three of the four species (i.e. Diploneis smithii, Cyclotella atomus and Synedra fasciculata) were present in both the pelagic and benthic habitat indicating the influence of resuspension. Cyclotella atomus is known to be indicative of turbulent eutrophic conditions (Wang et al., 2012), and both D. smithii and S. fasciculata are considered epipelic, i.e., benthic (Round et al., 1990; Kendrick et al., 1998). The presence of the latter two species in the pelagic habitat are thus explained by resuspension. Therefore, while an inverse relationship between microalgal diversity and nutrient enrichment has been observed in other studies (Watt, 1998; Agatz et al., 1999; Lemley et al., 2015), in this case, the higher planktonic and benthic index scores observed on Day 21 are most likely the result of the prevailing turbulent hydrological conditions, that hindered their effectiveness (i.e. biomass and diversity) as a bioindicator (Tirok and Scharler, 2014).

Characterised by a sigmoidal curve, the development of a mature diatom community on artificial substrata is defined by three phases. These include: (i) colonisation, (ii) logarithmic growth phase, and (iii) the upper asymptote phase indicating equilibrium between growth and loss factors (Tilley and Haushild, 1975; Desrosiers et al. 2014). Following a similar sigmoidal pattern, the epilithic algae on the glass slides indicated a significant increase in biomass following the nutrient-enriched freshwater inflow, reaching its maximum by Day 21 , followed by an asymptotic phase. By contrast, Desrosiers et al. (2014) reported maximum diatom growth on submerged plexiglass substrata in tropical oligotrophic marine environments only after a period of 35 days. Although the exponential growth phase generally occurs within the accepted colonization time of $28-35$ days, it is the availability of light and nutrients that controls the accrual phase pattern (Biggs, 1996). This was observed by Casartelli et al. (2016) where higher chl- $a$ concentrations on glass slides in a shallow mesotrophic reservoir during the dry season, in comparison to the wet season, due to high total nitrogen concentrations, water transparency and low rainfall was shown. Since the artificial structure holding the glass slides used during this study was suspended just below the water surface, light was not a limiting growth factor. Therefore, the significant increase in the epilithic algal biomass observed, from $1.5 \mathrm{mg} \cdot \mathrm{m}^{-2}$ (Day 14) to $6 \mathrm{mg} \cdot \mathrm{m}^{-2}$ (Day 21), can be attributed to the increased nutrient availability. Concomitant with the increased nutrient availability, the epilithic diatom community diversity, richness and evenness scores declined due to the increasing prevalence of the dominant species, i.e., Cocconeis placentula var. euglypta. This response was expected because eutrophication often leads to a single species dominating the community due to continuous nutrient inputs (Lemley et al., 2016). Considered a late colonizer, C. placentula var. euglypta is fast growing, responds well to disturbances and is efficient in taking up nutrients, i.e., is a good competitor for nutrients (Acs and Kiss, 1993; Kralj et at., 2006; Gari and Corigliano, 2007). Therefore, the epilithic species diversity declined from Day $7\left(H^{\prime}=1.2\right)$ to Day 28 $\left(H^{\prime}=0.7\right)$.

To effectively apply phytoplankton and MPB communities as indicators of change, the scale and timing of the investigation are important considerations. This largely depends on the response time of these communities to anthropogenically induced stresses. Not all ecological indicators are, however, transferable to other ecosystems (Lindenmayer and Likens, 2010). For this reason, the lack of a relationship between the phytoplankton and MPB communities and nutrients may mean that the factors that constitute loss (i.e. dilution and wind-driven circulation) in the St Lucia Estuary limited the algal growth despite the increased nutrient supply. Consequently, during periods of freshwater inflow, these natural communities are seemingly poor indicators of the agricultural nutrient input to the estuary. Therefore, since the epilithic algae grown on the glass slides were shown to be resilient to the freshwater inflow, the epilithic community was able to respond to the increased nutrient availability, i.e., low species diversity. According to the conceptual model of anthropogenically induced eutrophication in estuaries, changes in microalgal community dynamics (abundance, composition and richness) are a primary eutrophic response (Lemley et al., 2016). The use of the epilithic algal community grown on glass slides thus proved effective as an indicator of nutrient-induced changes.

While freshwater inflow is important in terms of the introduction of 'new' nutrients into the estuarine lake, it is important to take into consideration that in-situ remineralisation processes, concomitant with low water levels, can also elevate the DIN and DIP availability. For example, during the 2002-2012 dry phase DIN concentrations exceeding $100 \mu \mathrm{M}$ were observed in False Bay despite the area receiving no freshwater inflow (Perissinotto et al., 2013a). The continuous supply of DIN via the Mfolozi River inflow may potentially amplify the nutrient availability and subsequent persistence of the cyanobacterial blooms at the onset of the next drought cycle. Adopting an adaptive approach for routine water quality monitoring by using supplementary tools (i.e., artificial substrata) focused on detecting nutrient-induced change is therefore a necessity. This will allow for the timely application of management interventions (e.g., the restoration of parts of the Mkhuze and Mfolozi floodplain and associated wetlands) 
to mitigate the risk for larger scale and longer-term changes in ecosystem function as observed during the previous dry phase, i.e., simple food web structure in False Bay driven by the Cyanothece bloom (Carrasco and Perissinotto, 2012).

\section{CONCLUSION}

This study demonstrated the efficacy of artificial substrata as a monitoring tool to detect nutrient-enrichment and limit short-term hydrologically induced diatom variability. Both the epilithic algal biomass and diatom community index scores responded to the increased nutrient availability. This contrasted with the response of the phytoplankton and MPB which showed no discernible increase in biomass despite the higher nutrient availability. While the phytoplankton and MPB communities were limited by the freshwater inflow, the dominant diatoms identified still consisted of some nutrienttolerant species, i.e., Cyclotella atomus, Diatoma vulgaris and Nitzschia palea. The increased occurrence of nutrient-tolerant diatom species indicates that small-scale water quality related changes are already taking place in the estuary. However, since the phytoplankton and MPB community structural variables routinely used for monitoring to detect nutrient-induced changes proved ineffective as indicators in St Lucia's current wet phase, the incorporation of epilithic algae grown on an artificial substrate, i.e., glass microscope slides, should be considered as part of the routine water quality monitoring. In addition, given the size of the estuarine lake it is important that future research pertaining to this monitoring tool include the lake basins to test the effectiveness of this method across the entire ecosystem. This potential supplementary monitoring is especially important for Lake St. Lucia because re-establishing the connection with the Mfolozi River was considered key to restoring the health of the St Lucia Estuary (Van Niekerk et al., 2013), and it is therefore necessary to monitor the impacts of this change on estuarine health.

\section{ACKNOWLEDGMENTS}

This work is based on the research supported in part by the National Research Foundation of South Africa (Grant Numbers 102207). iSimangaliso Wetlands Park Authority is thanked for allowing access to operate in the St Lucia Estuary and Ezemvelo Wildlife Authority is thanked for assistance in field and general support. Peter Surendorff is thanked for logistical and technical support.

\section{REFERENCES}

ACQUAVITA A, ALEFFI IF, BENCI C, BETTOSO N, CREVATIN E, MILANI L, TAMBERLICH F, TONIATTI L, BARBIERI P, LICEN S and MATTASSI G (2015) Annual characterization of the nutrients and trophic state in a Mediterranean coastal lagoon: The Marano and Grado Lagoon (northern Adriatic Sea). Regional Stud. Mar. Sci. 2 132-144. https://doi.org/10.1016/j.rsma.2015.08.017

ACS E and KISS KT (1993) Colonization process of diatoms on artificial substrates in the River Danube near Budapest (Hungary). Hydrobiologia 269/270 307-315. https://doi.org/10.1007/ BF00028029

ADAMS JB (2014) A review of methods and frameworks used to determine the environmental water requirements of estuaries. Hydrol. Sci. J. 59 (3-4) 451-465. https://doi.org/10.1080/02626667. 2013.816426

ADAMS JB, NONDODA S and TAYLOR RH (2013) Macrophytes. In: Perissinotto R, Stretch D and Taylor R (eds) Ecology and Conservation of Estuarine Ecosystems: Lake St Lucia as a Global Model. Cambridge University Press, UK. https://doi.org/10.1017/
CBO9781139095723.013

AGATZ M, ASMUS RM and DEVENTER B (1999) Structural changes in the benthic diatom community along a eutrophication gradient on a tidal flat. Helgoland Mar. Res. 53 92-101. https://doi. org/10.1007/PL00012144

AKTAN Y, BALKIS, N and BALKIS N (2014) Seasonal variations of epipelic algal community in relation to environmental factors in the Istanbul Strait (the Bosphorus), Turkey. Mar. Pollut. Bull. 81 268-275. https://doi.org/10.1016/j.marpolbul.2014.01.027

ANDERSEN RA (2005) Algal Culturing Techniques. Phycological Society of America, Elsevier Academic Press, New York. 578 pp.

BATE GC and HEELAS BV (1975) Studies on the nitrate nutrition of two indigenous Rhodesian grasses. J. Appl. Ecol. 12 941-952. https://doi.org/10.2307/2402100

BATE GC, SMAILES, PA and ADAMS JB (2013) Epipelic diatoms in the estuaries of South Africa. Water SA 39 105-118. https://doi. org/10.4314/wsa.v39i1.11

BATE GC, SMAILES PA and ADAMS JB (2004) Benthic diatoms in the rivers and estuaries of South Africa. WRC Report No. TT 234/04. Water Research Commission, Pretoria.

BATE GC, WHITFIELD AK and FORBES AT (2011) A review of studies on the Mfolozi flood plain, with emphasis on information required by management for future reconnection of the river to the St Lucia system. WRC Report No. KV 255/10. Water Research Commission, Pretoria.

BATE GC, WHITFIELD AK, ADAMS JB, HUIZINGA P and WOOLDRIDGE TH (2002) The importance of the river- estuary interface (REI) zone in estuaries. Water SA 28 271-279. https://doi. org/10.4314/wsa.v28i3.4894

BIGGS BJF (1996) Patterns in benthic algae of streams. In: Stevenson RJ, Bothwell ML and Lowe RL (eds) Algal Ecology: Freshwater Benthic Ecosystems (eds.). Academic Press, San Diego. https://doi. org/10.1016/B978-012668450-6/50031-X

BOUVY M, ARFI R, BERNARD C, CARRÉ C, GOT P, PAGANO M and TROUSSELLIER M (2010) Estuarine microbial community characteristics as indicators of human-induced changes (Senegal River, West Africa). Estuar. Coast. Shelf Sci. 87 573-582. https://doi. org/10.1016/j.ecss.2010.02.015

CARRASCO NK, PERISSINOTTO R and PILLAY D (2010) Zooplankton of the St Lucia Estuary during the current drought cycle: a comparison between open- and closed-mouth conditions. Mar. Ecol. Progress Ser. 399 157-171. https://doi.org/10.3354/ meps08355

CASARTELLI MR, LAVAGNOLLI GJ and FERRAGUT C (2016) Periphyton biomass accrual rate changes over the colonization process in a shallow mesotrophic reservoir. Acta Limnol. Brasiliensia 28 1-9. https://doi.org/10.1590/S2179-975X0116

CHAPMAN D, JACKSON J and KREBS F (1996) Chapter 11-Biological Monitoring. In: Bartram J and Ballance R (eds) Water Quality Monitoring - A Practical Guide to the Design and Implementation of Freshwater Quality Studies and Monitoring Programmes. United Nations Environmental Programme and the World Health Organization, London. ISBN 0419223207.

DALU T, FRONEMAN WP, CHARL LD and RICHOUX NB (2014) Colonisation and community structure of benthic diatoms on artificial substrates following a major flood event: A case of the Kowie River (Eastern Cape, South Africa). Water SA 40 471-480. https://doi.org/10.4314/wsa.v40i3.10

DELA-CRUZ J, PRITCHARD T, GORDON G and AJANI P (2006) The use of periphytic diatoms as a means of assessing impacts of point source inorganic nutrient pollution in southeastern Australia. Freshwater Biol. 51 951-972. https://doi. org/10.1111/j.1365-2427.2006.01537.x

DELGADO C and PARDO I (2014) Comparison of benthic diatoms from Mediterranean and Atlantic Spanish streams: Community changes in relation to environmental factors. Aquat. Bot. 120304 314. https://doi.org/10.1016/j.aquabot.2014.09.010

DELL INC (2016) Dell Statistica (data analysis software system), version 13. software.dell.com.

DESROSIERS C, LEFLAIVE J, EULIN A and TEN-HAGE L (2013) Bioindicators in marine waters: Benthic diatoms as a tool to assess water quality from eutrophic to oligotrophic coastal ecosystems. Ecol. Indic. 32 25-34. https://doi.org/10.1016/j.ecolind.2013.02.021 
DESROSIERS C, LEFLAIVE J, EULIN A and TEN-HAGE L (2014) Optimal colonization and growth of marine benthic diatoms on artificial substrata: protocol for a routine use in bioindication. J. Appl. Phycol. 26 1759-1771. https://doi.org/10.1007/ s10811-013-0204-3

DIX N, PHLIPS E and SUSCY P (2013) Factors controlling phytoplankton biomass in a subtropical coastal lagoon: Relative scales of influence. Estuar. Coasts 36 981-996. https://doi. org/10.1007/s12237-013-9613-4

DWS (DEPARTMENT OF WATER AND SANITATION, SOUTH AFRICA) (2017) Resource Quality Services water quality monitoring sites grouped by water management area. URL: http://www.dwaf. gov. za/iwgs/wms/data/WMS_WMA_txt.asp (Accessed July 2017).

ELIAS CL, ROCHA RJM, FEIO MJ, FIGUEIRA E and ALMEIDA SFP (2017) Influence of the colonizing substrate on diatom assemblages and implications for bioassessment: a mesocosm experiment. Aquat. Ecol. 51 145-158. https://doi.org/10.1007/s10452-016-9605-0

ELLIOTT M and QUINTINO V (2007) The Estaurine Quality Paradox, environmental homeostasis and the difficulty of detecting anthropogenic stress in naturally stressed areas. Mar. Pollut. Bull. 54 640-645. https://doi.org/10.1016/j.marpolbul.2007.02.003

EULIN A and COHU R (1998) Epilithic diatom communities during the colonization of artificial substrates in the River Garonne (France). Comparison with the natural communities. Arch. Hydrobiol. 143 79-106. https://doi.org/10.1127/ archiv-hydrobiol/143/1998/79

GARI EN and CORIGLIANO MC (2007) Spatial and temporal variations of Cocconeis placentula var. euglypta (Ehrenb.) 1854 Grunow, 1884 in drift and periphyton. Braz. J. Biol. 67 587-595. https://doi.org/10.1590/S1519-69842007000400002

GORDON N, PERISSINOTTO R and MIRANDA NAF (2016) Microalgal dynamics in a shallow estuarine lake: Transition from drought to wet conditions. Limnologica 60 20-30. https://doi. org/10.1016/j.limno.2016.05.010

GRENFELL SE and ELLERY WN (2009) Hydrology, sediment transport dynamics and geomorphology of a variable flow river: The Mfolozi River, South Africa. Water SA 35 271-282.

HARTLEY B (1996) An Atlas of British Diatoms. Biopress Ltd, Bristol. $601 \mathrm{pp}$.

HILMER T (1990) Factors influencing the estimation of primary productivity in small estuaries. PhD thesis. University of Port Elizabeth.

KENDRICK GA, LANGTRY S, FITZPATRICK J, GRIFFITHS $\mathrm{R}$ and JACOBY CA (1998) Benthic microalgae and nutrient dynamics in wave-disturbed environments in Marmion Lagoon, Western Australia, compared with less disturbed mesocosms. J. Exp. Mar. Biol. Ecol. 228 83-105. https://doi.org/10.1016/ S0022-0981(98)00011-2

KRAJL K, PLENKOVIC-MORAJ A, GLIGORA M, PRIMC-HABDIJA B and SIPOS L (2006) Structure of periphytic community on artificial substrata: influence of depth, slide orientation and colonization time in karstic Lake Visovacko, Croatia. Hydrobiol. 560 249-258. https://doi.org/10.1007/s10750-005-1330-y

LANGE-BERTALOT H (2000) Iconographia Diatomologica, Volume 7. Koeltz Scientific Books, Germany. 925 pp.

LEMLEY DA, ADAMS JB and BATE GC (2016) A review of microalgae as indicators in South African estuaries. S. Afr. J. Bot. 107 12-20. https://doi.org/10.1016/j.sajb.2016.04.008

LEMLEY DA, ADAMS JB and STRYDOM NA (2017) Testing the efficacy of an estuarine eutrophic condition index: Does it account for shifts in flow conditions? Ecol. Indic. 74 357-370.

LEMLEY DA, NUNES M and ADAMS JB (2018) Estuarine algal responses to increasing nitrate concentrations during closed mouth conditions of oligotrophic systems: A laboratory microcosm experiment. Bot. Mar. 61 (6) 559-572. https://doi.org/10.1515/ bot-2018-0027

LEMLEY DA, ADAMS JB, TALJAARD S and STRYDOM NA (2015) Towards the classification of eutrophic conditions in estuaries. Estuar. Coast. Shelf Sci. 164 221-232. https://doi.org/10.1016/j. ecss.2015.07.033

LINDENMAYER DB and LIKENS GE (2010) The science and application of ecological monitoring. Biol. Conserv. 143 1317-1328. https://doi.org/10.1016/j.biocon.2010.02.013
MINNE C (2003) Diatoms as indicators of water quality in estuaries. MSc thesis, University of Port Elizabeth.

MITCHELL SB, JENNERJAHN TC, VIZZINI S and ZHANG W (2015) Changes to processes in estuaries and coastal waters due to intense multiple pressures-An introduction and synthesis. Estuar. Coast. Shelf Sci. 156 1-6. https://doi.org/10.1016/j.ecss.2014.12.027

NUNES M, ADAMS JB, BATE GC and BORNMAN TG (2017) Abiotic characteristics and microalgal dynamics in South Africa's largest estuarine lake during a wet to dry transitional phase. Estuar. Coast. Shelf Sci. 198 236-248. https://doi.org/10.1016/j.ecss.2017.09.009

NUNES M, ADAMS JB and RISHWORTH GM (2018) Shifts in phytoplankton community structure in response to hydrological changes in the shallow St Lucia Estuary. Mar. Pollut. Bull. 128 275286. https://doi.org/10.1016/j.marpolbul.2018.01.035

NUSCH EA (1980) Comparison of different methods for chlorophyll and phaeopigment determination. Arch. Hydrobiol., Beiheft Ergebnise Limnol. 14 14-36.

O'BRIEN A, TOWNSEND K, HALE R, SHARLEY D and PETTIGROVE V (2016) How is ecosystem health defined and measured? A critical review of freshwater and estuarine studies. Ecol. Indic. 69 722-729. https://doi.org/10.1016/j. ecolind.2016.05.004

ODEBRECHT C, ABREU PC and CARSTENSEN J (2015) Retention time generates short-term phytoplankton blooms in a shallow microtidal subtropical estuary. Estuar. Coast. Shelf Sci. 162 35-44. https://doi.org/10.1016/j.ecss.2015.03.004

PAERL HW, ROSSIGNOL KL, HALL SN, PEIERLS BL and WETZ MS (2010) Phytoplankton community indicators of short-and longterm ecological change in the anthropogenically and climatically impacted Neuse River Estuary, North Carolina, USA. Estuar. Coasts 33 485-497. https://doi.org/10.1007/s12237-009-9137-0

PARSONS TR, MAITA Y and LALLI CM (1984) A manual of Chemical and Biological Methods for Seawater Analysis. Pergamon Press, New York.

PERISSINOTTO R, CARRASCO NK and TAYLOR RH (2013a) Physico-chemical environment. In: Perissinotto R, Stretch DD and Taylor R (eds) Ecology and Conservation of Estuarine Ecosystems: Lake St Lucia as a Global Model. Cambridge University Press, UK.

PERISSINOTTO R, STRETCH DD and TAYLOR RH (2013b) Ecology and Conservation of Estuarine Ecosystems: Lake St Lucia as a Global Model. Cambridge University Press, UK.

PEIRSON W, DAVEY E, JONES A, HADWEN W, BISHOP K, BEGER M, CAPON S, FAIRWEATHER P, CREESE B, SMITH TF, GRAY $\mathrm{L}$ and TOMLINSON R (2015) Opportunistic management of estuaries under climate change: A new adaptive decision-making framework and its practical application. J. Environ. Manage. 163 217-223. https://doi.org/10.1016/j.jenvman.2015.08.021

RODRIGUEZ P and PIZARRO H (2015) Phytoplankton and periphyton production and its relation to temperature in a humic lagoon. Limnologica 55 9-12. https://doi.org/10.1016/j. limno.2015.10.003

ROUND FE (1981) The Ecology of Algae. Cambridge University Press, London. 653 pp.

ROUND FE, CRAWFORD RM and MANN DG (1990) The Diatoms, Biology and Morphology of the Genera. Cambridge University Press. Cambridge. 747 pp.

SANCHEZ ML, RODRIQUEZ P, TORREMORELL AM, IZAGUIRRE I and PIZARRO H (2017) Phytoplankton and Periphyton primary production in clear and turbid shallow lakes: Influences of the light environment on the interactions between these communities. Wetlands 37 67-77. https://doi.org/10.1007/s13157-016-0840-X

SHANNON CE and WIENER W (1949) The Mathematical Theory of Communications. University of IIinois Press, Urbana. $117 \mathrm{pp}$.

SNOW GC (2016) Determining the health of river-dominated estuaries using microalgal biomass and community composition. S. Afr. J. Bot. 107 21-30. https://doi.org/10.1016/j.sajb.2016.02.201

TAYLOR GC, ARCHIBALD CGM and HARDING WR (2007) An illustrated guide to some common diatom species from South Africa. WRC Report No. TT 282/07. Water Research Commission, Pretoria.

TAYLOR RH (2006) Ecological responses to changes in the physical environment of the St Lucia Estuary. PhD thesis, Norwegian University of Life Sciences. 
TILLEY LJ and HAUSHILD WL (1975) Use of productivity of periphyton to estimate water quality. J. Water Pollut. Control Fed. 42 2157-2171.

TIROK K and SCHARLER UM (2014) Influence of variable water depth and turbidity on microalgae production in a shallow estuarine lake system - A modelling study. Estuar. Coast Shelf Sci. 146 111-127. https://doi.org/10.1016/j.ecss.2014.05.011

TWEEDLEY JR, WARWICK RM and POTTER IC (2015) Can biotic indicators distinguish between natural and anthropogenic environmental stress in estuaries? J. Sea Res. 102 10-21. https://doi. org/10.1016/j.seares.2015.04.001

VAN NIEKERK L, ADAMS JB, BATE GC, FORBES AT, FORBES NT, HUIZINGA P, LAMBERTH SJ, MACKAY CF, PETERSEN C, TALJAARD S, WEERTS SP, WHITFIELD AK and WOOLDRIDGE TH (2013) Country-wide assessment of estuary health: An approach for integrating pressures and ecosystem response in a data limited environment. Estuar. Coast. Shelf Sci. 130 239-251. https://doi.org/10.1016/j.ecss.2013.05.006

WANG P, SHEN H and XIE P (2012) Can hydrodynamics change phosphorus strategies of diatoms? Nutrient levels and diatom blooms in lotic and lentic ecosystems. Microbiol. Aquat. Syst. 63 369-382. https://doi.org/10.1007/s00248-011-9917-5

WATT DA (1998) Estuaries of contrasting trophic status in KwazuluNatal, South Africa. Estuar. Coast. Shelf Sci. 47 209-216. https:// doi.org/10.1006/ecss.1998.0345

WHITFIELD AK (2014) Proceedings of the St Lucia natural science workshop: Change, connectivity and conservation in a major wetland system. WRC Report No. TT 582/13. Water Research Commission, Pretoria.

WHITFIELD AK, BATE GC, FORBES T and TAYLOR RH (2013) Relinkage of the Mfolozi River to the St Lucia estuarine system urgent imperative for the long-term management of a Ramsar and World Heritage Site. Aquat. Ecosyst. Health Manage. 16 104-110. https://doi.org/10.1080/14634988.2013.759081

WHITFIELD AK and TAYLOR R (2009) A review of the importance of freshwater inflow to the future conservation of Lake St Lucia. Aquat. Conserv. Mar. Freshwater Ecosyst. 19 838-848. https://doi. org/10.1002/aqc.1061

\section{APPENDIX}

TABLE A1

The dominant diatom species (> 10\%) recorded in St Lucia Estuary during the July/August 2017 sampling period. P-Phytoplankton, M-Microphytobenthos and E-Epilithic

\begin{tabular}{|c|c|c|c|c|c|c|c|c|c|c|c|c|c|}
\hline \multirow[t]{2}{*}{ Species } & \multirow[t]{2}{*}{ Code } & \multicolumn{3}{|c|}{ WEEK 1} & \multicolumn{3}{|c|}{ WEEK 2} & \multicolumn{3}{|c|}{ WEEK 3} & \multicolumn{3}{|c|}{ WEEK 4} \\
\hline & & $\mathbf{P}$ & M & E & $\mathbf{P}$ & $M$ & $\mathrm{E}$ & $\mathbf{P}$ & M & $\mathrm{E}$ & $\mathbf{P}$ & M & $\mathrm{E}$ \\
\hline Amphora coffeiformis (Agardh) Kützing & AMPHCOFF & 0 & 0 & 1.1 & 0 & 0 & 2.4 & 0 & 15 & 1.2 & 0 & 0 & 0.3 \\
\hline $\begin{array}{l}\text { Cocconeis placentula var. euglypta } \\
\text { (Ehrenberg) Grunow }\end{array}$ & COCCEUGL & 0 & 7.1 & 62.6 & 0 & 50 & 76.4 & 0 & 0 & 78 & 0 & 0 & 88.1 \\
\hline Cyclotella atomus Hustedt & CYCLATOM & 52.2 & 35.7 & 0 & 25 & 0 & 0 & 33.3 & 23.1 & 0 & 59 & 40 & 0 \\
\hline Cyclotella glomerata H.Bachmann & CYCLGLOM & 0 & 0 & 0 & 0 & 0 & 0 & 6 & 0 & 0 & 5.1 & 0 & 0 \\
\hline Diatoma vulgaris Bory & DIATVULG & 0 & 0 & 0 & 0 & 0 & 0 & 0 & 0 & 0 & 0 & 60 & 0 \\
\hline Diploneis smithii (Brébisson) Cleve & DIPLSMIT & 8.7 & 28.5 & 0.3 & 0 & 50 & 0 & 11.1 & 15.4 & 0.3 & 20.5 & 0 & 0 \\
\hline Frustulia sp. & FRUSTULI & 17.4 & 0 & 0 & 0 & 0 & 0 & 2.7 & 0 & 0 & 2.6 & 0 & 0 \\
\hline Hyalodiscus radiatus (O’Meara) Grunow & HYALRADI & 0 & 28.5 & 0 & 0 & 0 & 0 & 0 & 0 & 0 & 0 & 0 & 0 \\
\hline Nitzschia agnewii Cholnoky & NITZAGNE & 0 & 0 & 0 & 0 & 0 & 0 & 11.1 & 0 & 0 & 0 & 0 & 0 \\
\hline Nitzschia palea (Kützing) W. Smith & NITZPALE & 4.3 & 0 & 0 & 50 & 0 & 2.1 & 2.8 & 0 & 0.6 & 0 & 0 & 0 \\
\hline Synedra fasciculata (C.Agardh) Kützing & SYNEFASC & 4.3 & 0 & 13.4 & 8.3 & 0 & 2.7 & 11.1 & 15.4 & 3.3 & 0 & 0 & 1 \\
\hline
\end{tabular}

